\title{
Focusing Educational Technology Research on Informal Learning Environments
}

\author{
Richard A. Schwier \\ University of Saskatchewan, Canada \\ It was only that and light was all it needed and a certain cleanness and order. Some \\ lived in it and never felt it but he knew it all was nada y pues nada y nada y pues nada. \\ Ernest Hemingway (1926). A Clean Well-Lighted Place
}

In recent years, we have witnessed deep challenges to how we think about learning, learning design, and learning environments. I would like to make a simple observation, and I will reveal it first, so you can go about your business if you have no interest in it. Here is my proposition: as educational technology professionals and as instructional designers, we need to embrace the idea of informal learning and make it our own. We may need to support formal learning, and in fact, we may even make most of our livings from it; but we should not give our hearts over to formal learning. The excitement, the potential and the future of learning is on the informal side of the ledger. Perhaps most importantly, it is where the fun is hiding in our profession.

A little background and a few definitions are necessary to make sense of this proposition. Limiting our current understanding of how learners make use of educational technology is the fact that existing research focuses almost exclusively on formal learning environments-post-secondary courses managed by institutions of higher learning or conventional K-12 curricula.

Formal environments often require learners to engage each other online in specific, externally defined ways, whereas non-formal environments impose fewer controls on learner activities, and informal environments relinquish control of the learning and the conditions of learning to the learners. Formal educational contexts are usually characterized by learners in classes being taught by teachers who deliver comprehensive, multi-year curricula, which is institutionally bound to a graduated system of certification (Coombs, 1985).

Non-formal learning contexts, by contrast, "comprise all other organized, systematic educational activity which is carried out in society, whether offered by educational institutions or any other agency. It is aimed at facilitating selected types of learning on the part of particular sub-groups of the population (Selman, Cooke, Selman, and Dampier, 1998, p.26). For example, non-formal education may include such activities as professional development interest groups or community education initiatives. These alternative group learning contexts are usually characterized by a sharing of expertise and knowledge amongst the membership, which may or may not include a "content expert." 
Extrapolating from definitions of formal learning environments by Eraut (2000) and Livingstone (1999; 2001), non-formal environments can be characterized by:

- a prescribed but unfettered learning environment.

- learning that is intentional, not casual or serendipitous.

- a structure for learning defined externally, usually by an instructor or organization.

- the presence of an instructor or facilitator who organizes learning events and activities

- learner control of the objectives of learning; personal intentions outweigh externally defined intentions

- learner control of the level of participation in learning activities and events.

- organizational expectations around participation, investment, persistence, and completion

- internal, self-defined outcomes guide the learning path

In sharp contrast, informal education is often characterized as unorganized (not disorganized), unsystematic, and possibly even unintentional (Selman, et.al., 1998). This type of learning is the lifelong process of learning by which people acquire and accumulate knowledge, skills, attitudes and insights gathered through intention or serendipity, to answer immediate questions or acquire wisdom from a lifetime of experiences. In other words, informal learning can address all kinds of questions, but it is always driven by learner needs or curiosity.

Informal learning may be characterized by:

- A learning environment that is chosen, controlled and in some cases, invented, by the person(s) doing the learning;

- Learning that may be intentional or casual and serendipitous;

- The absence of an identified instructor or assigned leader who controls the environmentinformal learning is self-directed;

- Learner defined goals that may range from amorphous to precise, and which guide the learning path;

- No organizational expectations around participation, investment, persistence and completion.

Here is the challenge. In educational technology we see new opportunities for learning popping up everywhere around us. From emerging avenues for personal expression to the stunning speed and efficiency of social networking, we know that the ways of learning are already influencing the types of learning that is happening. However, formal institutions of learning are having a very difficult time responding to the opportunities these kinds of systems afford. We hear talk about "thinning the walls" of educational institutions and we regularly hear that educators' roles are changing from managing content to connecting learners in new ways to other learners, resources, and expertise. A wonderful quote from Wil Richardson may say it best:

"We as educators need to reconsider our roles in students' lives, to think of ourselves as connectors first and experts second."

I am sure Richardson and others are correct, but I am less convinced that it is the best use of our time to try to drag along resistant organizations, resistant people, resistant approaches when the 
lessons of new learning are all around us. I am not arguing that we should ignore the challenge of introducing this type of change into the school systems. We should. But we also need to realize that there is already a great deal of vibrancy in the new systems of learning - the informal systems of learning - that deserve our attention.

This is where research comes in. I think it is time for research in educational technology to make a serious and sustained effort to understand informal learning in technology-based environments. We need to find out how learning happens in online social environments and where it does not. We need to inquire into the very nature and quality of learning that is achieved in informal environments. We need to understand how we can support a new kind of engagement by learners so they can invent new ways to learn and find new paths to solutions for their own problems. In other words, we need to pay considerable attention to the natural and effervescent processes of learning we see being invented. The data are lying in front of us, inviting exploration. Our challenge is sorting out the questions worth asking, and inventing ways to conduct serious, powerful research into those questions. But first, we need to be curious.

\section{References}

Coombs, P. H. (1985). The world crisis in education: The view from the Eighties. New York: Oxford.

Eraut, M. (2000). Non-formal learning and tacit knowledge in professional work. British Journal of Educational Psychology, 70(1), 113-136.

Hemingway, E. (1926). A clean well-lighted place. Retrieved December 14, 2009 from http://www.mrbauld.com/hemclean.html.

Livingstone, D.W. (1999). Exploring the icebergs of adult learning: Findings of the first Canadian survey of informal learning practices. Canadian Journal for the Study of Adult Education, 13(2), 49-72.

Livingstone, D.W. (2001). Adults' Informal Learning: Definitions, findings, gaps and future research, NALL working paper No. 21, OISE/UT, Toronto. Retrieved July 28, 2008 from http://www.oise.utoronto.ca/depts/sese/csew/nall/res/21adultsifnormallearning.htm.

Reeves, T.C., Herrington, J. \& Oliver, R. (2004). A development research agenda for online collaborative learning. Educational Technology Research and Development, 52(4), 2004, 53 65.

Richardson, W. (2008, December). World without walls: Learning well with others: How to teach when learning is everywhere. Edutopia. Retrieved December 14, 2009 from http://www.edutopia.org/collaboration-age-technology-will-richardson.

Selman, G., Cooke, M. Selman, M., \& Dampier, P. (1998). The foundations of adult education in Canada. $\left(2^{\text {nd }}\right.$ ed). Toronto: Thompson Educational Publishing.

Correspondence: Richard A. Schwier, Professor, Curriculum Studies, College of Education, University of Saskatchewan, 28 Campus Dr., Saskatoon, SK. S7NOX1, Canada. 